up to it, is a misleading method. The only fertile method in such inquiries as ours is induction from the facts, and to this I most unflinchingly invite your readers.

If the facts are susceptible of a more reasonable explanation than that I have given, by all means let ns have it, and I will surrender. At present I am a more incorrigible heretic than ever. I bope I have not said one offensive or irritating word. If I have, may it be cancelled and forgiven. In conclusion, let me quote a most weighty sentence or two from one whom both Mr. Reid and myself will agree with honouring and paying some deference to. Professor Huxley, in his address to the Geological Society for 1869, said, "To my mind there appears to be no sort of necessary theoretical antagonism between Catastrophism and Uniformitarianism. On the contrary, it is very conceivable that catastrophes may be part and parcel of uniformity. Let me illustrate my case by analogy. The working of a clock is a model of uniform action. Good timekeeping means uniformity of action. But the striking of the clock is essentially a catastrophe. The hammer might be made to blow up a barrel of gunpowder or turn on a deluge of water; and by proper arrangement the clock, instead of marking the hours, might strike at all sorts of irregular intervals, never twice alike in the intervals, force, or number of its blows. Nevertheless, all these irregular and apparently lawless catastrophes would be the result of an absolutely Uniformitarian action, and we might have two schools of clock theorists, one studying the hammer and the other the pendulum." These are weighty words, to every one of which I subscribe. In objecting to the current doctrine of Uniformity, it may be suggested that I am objecting to the government of the universe by law-a view I repudiate altogether. What I say is that the law which governs the universe is not to be grasped by those who will not look beyond what is passing now at their elbows. A beautiful city like Lisbon, where I was born, bas existed for 100 years in peaceful prosperity ; and yet in 1753 it was overwhelmed by the most terrible cataclysm that is mentioned in modern history. That cataclysm is the type of others. How can such an event, the only one of its extent and kind recorded in the West, be explained by the current school of English geologists? To Professor Huxley, and those who hold with him, such a cataclysm is as much the result of law as the peace which has succeeded; and to some of us a cataclysm of a much greater extent, involving a great revolution in current geological views about Post-Glacial geology, is just as reasonable a priori, while we affirm that it is abundantly required to explain the facts.

Henry H. Howorth.

Derby House, Eccles, Nov. 5th, 1881.

COAL-MEASURES UNDER THE NEW RED SANDSTONES.

Sin,-Permit me to say that the discovery of limestone bands at Winwick beneath the Trias is not quite so novel a one as both Mr. Strahan and Mr. De Rance appear to think.

In a letter of mine to the Liverpool Daily Post, dated 15 Sept. 
1872, and afterwards copied into Nature, Sept. 19, 1872, the following passage occurs :- "But a well-boring at Winwick, after penetrating 150 feet of Red Sandstone, the upper part of which is placed with the pebble beds in the feological Survey sheet, was sunk 210 feet through strata consisting of hard rock, stiff red marl, red and white sandstone, with a zone of limestone bands at the base, the boring terminating at 360 feet from the surface, in hard rock."

In this letter the possibility of finding workable coal under the Trias is fully discussed. I further observed that I " was inclined to think" that these beds "belong to the Permian rather than to the Upper Coal-measures." The borings through the Trias at St. Helen's have been made since this letter was written.

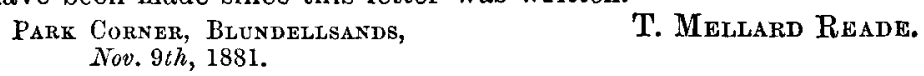

T. Mellakd Reade.

\section{DR. CALLAWAY'S VIEWS ON ANGLESEY GEOLOGY.}

Sir,-At page 423 of the September Number of this Magazine, Dr. Callaway states, speaking of the Geology of Anglesey, "that in no case are there any signs of a transition between the altered and unaltered beds." It is not quite clear to what beds he refers as altered or metamorphic beds; but if he has in view, as I imagine he has, the great gnarled series of Anglesey, which occupies the whole northern part of the island, I venture to take serious exception to his statement. This area of so-called metamorphic rock is represented on the Survey Map as bounded on the south by a great curved fault. On the coast at Porth Corwg, near Point Alianus, where the fault is represented as running out to sea, a fault undoubtedly does occur, and the gnarled beds are there seen to rest against the shales. As far as I know, this fault is actually seen nowhere else. It has been assumed to exist, as the most plausible explanation of the stratigraphy of the district, and has been so indicated on the map. There are various circumstances which suggest that the line laid down on the map is not the line a great fault would take, and I am in a position to state that no fault occurs at two points (at any rate) of the line indicated; for a distinct passage can be seen and traced inch by inch from the fossiliferous shales to the beds marked "altered Cambrian" on the Survey Map, and which Prof. Hughes calls the "gnarled series," This passage is shown on the slopes of the north side of Pare's Mountain, where bare rock crops out at the surface for some distance, and the character and texture of the rocks can be distinctly observed. Also at Hafod-onen, near Rhosgoch Station, where, on the bared surface of the farm-yard, the two series can be seen passing into one another, the one dipping under the other. I do not assert that fossiliferous Cambrian shales pass into metamorphic rocks, but I do assert that I have seen such shales pass into beds which Dr. Callaway has included under the head metamorphic. If the term metamorphic is used in any strict sense as implying a re-arrangement and crystallizing of mineral constituents, I do not see how it can be applied indiscriminately to the "guarled series." Parts of the Llandovery 